\title{
VOF-DEM 連成モデルによる捨石堰の破壊予測
}

\author{
DESTRUCTION PREDICTION OF A RUBBLE MOUND WEIR \\ USING VOF-DEM COUPLED MODEL
}

\author{
前野詩朗 ${ }^{1} \cdot$ 富田晃生 ${ }^{2} \cdot$ 脇野修平 $^{3}$ \\ Shiro MAENO, Akio TOMITA and Shuhei WAKINO \\ 1 正会員 工博 岡山大学准教授 環境学研究科社会基盤環境学専攻（† 700-8530 岡山市津島中 3-1-1) \\ 2 学生会員 岡山大学環境学研究科社会基盤環境学専攻修士課程（干700-8530 岡山市津島中 3-1-1) \\ ${ }^{3}$ 正会員 広島県尾三地域事務所建設局工務第二課（干723-8520 三原市円一町 2-4-1）
}

\begin{abstract}
Nature friendly hydraulic structures such as a rubble mound weir have attracted attention in recent years. Therefore, it is important to establish an analytical model to analyze the flow around such a porous weir. The aim of this study is to develop a destruction prediction model for the rubble mound weir under a gradual increase of discharge. The VOF (Volume of Fluid) method was used for the flow analysis around and through the rubble mound weir, and the DEM (Distinct Element Method) was used to express the failure process. A proposed VOF-DEM coupled model can feed back the movement of the DEM particles to the flow analysis of the VOF. It is confirmed that the proposed model can reproduce the step by step destruction of the rubble mound weir similar to the experimental results.
\end{abstract}

Key Words : nature friendly structure, rubble mound weir, natural stone, VOF, DEM

\section{1. はじめに}

近年，河川環境を保護するために自然にやさしい材料 を用いた多自然川づくりが全国各地で進められており， その中でも不透過性の堰の代替構造物として自然石を用 いた堰 (以下, 捨石堰と呼ぶ) の利用が期待されている. このような石碩を用いた透過性の堰の実用化を目指し て, 道奥ら ${ }^{1,2,23)}$ は, 矩形の捨石堰を用いて実験的かつ理 論的検討を進め, 非越流時の夕ならず越流時の「水位一 流量」の関係を明らかにした，また，著者ら ${ }^{4), 55,6)}$ は，台 形の捨石堰を用いて堰の破壊過程について実験的な検討 を行うとともに石磎の初動機構に着目した破壊モデルを 提案し, 捨石堰の破壊が堰下流法面で段階的に進行する ことや，石㗂の初動が石碩の転倒により生じることを明 らかにしている.さらに，波浪場のために開発された磯 部ら のの数值波動水路をもとに改良した VOF(Volume of Fluid)法を用いて河川の流れを再現し, 捨石堰の流況解析 を行った ${ }^{8)}$. その結果, VOF 法が河川の流れに対しても 有効であることを示し，石碩の大きさの違いを多孔質体 の抵抗の項に取り入れることで堰上げ効果の違いを表現 した。 また，基礎式中に多孔質抵抗として層流抵抗と乱 流抵抗の両者を考慮した抵抗則を導入することによっ て，多孔質堰周辺の流れを精度よく再現できる流況解析 モデルを提案した.

一方, VOF 法と個別要素法(DEM; Distinct Element Method) とを併用して流体解析と粒状態構造物の変形を

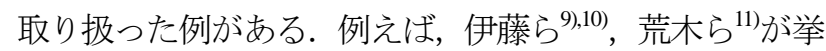
げられるが，これまでの研究では粒子の移動が流れに考 慮されていないか，もしくは，変形が落ち着くまで流体 解析に反映させないものや, 変形による間隙率の変化が 考慮されていないものなど，連成方法に課題があり，粒 子と流体の相互応答がうまく表現されていないものが多 い. また, 前野ら ${ }^{12}$ は，DEM を用いて捨石堰の破壊シ ミュレーションを行っているが，前述の解析例と同様に 流れ場との連成が考慮されていない点が課題であった.

以上のことを考慮して, 本研究では, 捨石堰を対象と して流量を徐々に増加させた際の流体力の変化を VOF 法により計算し，得られた流体力を石碩に働く作用力と して DEM 解析に順次組み込むことで，捨石堰の破壊過 程を捉えるシミュレーションを行う。ささらに, VOF 法の 解析に石㗂の移動もフィードバックすることで, 捨石堰 の破壊に伴う流れや流体力の変化も追跡し, 従来の研究 で明らかにされている捨石堰の段階的な破壊が再現でき るかを確認する．また，過去の水理模型による破壊実験 との比較によって, 解析モデルの妥当性を検証する.

\section{2. 解析の概要}




\section{（1） VOF 法の概要}

多孔質体内部の流れを再現するために，本研究では， Edward et al. $\left.{ }^{13}\right)$ や道奥 $~^{14)}$ と同様に捨石堰の透過性の効果 を間隙率 $n$ を用いて表した基礎式を用いることにする. 以下に連続式，運動方程式，並びに VOF 関数 $F$ の移流 項を示す.

$$
\begin{gathered}
\frac{\partial u}{\partial x}+\frac{\partial w}{\partial z}=0 \\
n \frac{\partial u}{\partial t}+\frac{\partial u u}{\partial x}+\frac{\partial w u}{\partial z}=-n^{2}\left(\frac{1}{\rho} \frac{\partial p}{\partial x}-g_{x}-R_{x}\right) \\
+\frac{\partial}{\partial x}\left(n \nu_{e}\left[2 \frac{\partial u}{\partial x}\right]\right)+\frac{\partial}{\partial z}\left(n \nu_{e}\left[\frac{\partial u}{\partial z}+\frac{\partial w}{\partial x}\right]\right)-\frac{2}{3} \frac{\partial k}{\partial x} \\
n \frac{\partial w}{\partial t}+\frac{\partial u w}{\partial x}+\frac{\partial w w}{\partial z}=-n^{2}\left(\frac{1}{\rho} \frac{\partial p}{\partial z}-g_{z}-R_{z}\right) \\
+\frac{\partial}{\partial x}\left(n \nu_{e}\left[\frac{\partial w}{\partial x}+\frac{\partial u}{\partial z}\right]\right)+\frac{\partial}{\partial z}\left(n \nu_{e}\left[2 \frac{\partial w}{\partial z}\right]\right)-\frac{2}{3} \frac{\partial k}{\partial z} \\
n \frac{\partial F}{\partial t}+\frac{\partial u F}{\partial x}+\frac{\partial w F}{\partial z}=0
\end{gathered}
$$

ここに, $x, z$ : 水平, 鉛直座標, $u, w$ : 流速の水平, 鉛 直成分(多孔質部は見かけの流速), $\rho$ : 流体密度, $p$ : 圧力, $k$ : 乱流エネルギー, $\varepsilon$ : 乱流エネルギ一散逸率, $\nu_{e}$ : 分子動粘性係数 $\nu$ と渦動粘性係数 $\nu_{t}$ の和, $g_{x}, g_{z}$ : $x, z$ 方向の加速度, $R_{x}, R_{z}: x, z$ 方向の抵抗力である. また，乱流モデルについては標準型 $k-\varepsilon$ モデルを用い た. ここで, $R_{x}, R_{z}$ については前野ら $\left.{ }^{15}\right)$ と同様に, 個有 透水係数と呼ばれる面積の次元を持つ透水係数 $K$, 乱れ による抵抗係数 $C$ を用いて, 次式で与える.

$$
\begin{gathered}
R_{x}=u\left(\frac{\nu}{K}+\frac{C}{\sqrt{K}} \sqrt{u^{2}+w^{2}}\right) \\
R_{z}=w\left(\frac{\nu}{K}+\frac{C}{\sqrt{K}} \sqrt{u^{2}+w^{2}}\right) \\
K=n^{3} D_{s p}^{2} /\left\{k_{1}(1-n)^{2}\right\}, \quad C=k_{2} / \sqrt{k_{1} n^{3}}
\end{gathered}
$$

ここに, $\nu$ :動粘性係数, $u, w: x$ 方向及び $z$ 方向のみか けの流速, $n$ : 間隙率, $D_{s p}$ : 粒径, $k_{1}, k_{2}$ : 層流抵抗及び 乱流抵抗の係数である. また, $\left(k_{1}, k_{2}\right)$ については, 道 奥ら ${ }^{14)}$ が用いた方法を参考に, 非越流流れと越流流れ 2 つのケースについて, 実験值と解析值の水深の誤差を最 小にする $\left(k_{1}, k_{2}\right)$ を数值実験的に求め, $\left(k_{1}, k_{2}\right)=(200$, 2.8)とした.

\section{（2）個別要素法の概要}

個別要素法では，堰を構成する石碟を剛体として仮定 している.さらに石碩を円形と仮定し，摩擦係数を与え ることによって捨石同士の噛み合わせを表現している. 粒子間の相互作用は弾性スプリングと粘性ダッシュポッ トで表現し，各粒子の運動方程式を計算することによっ

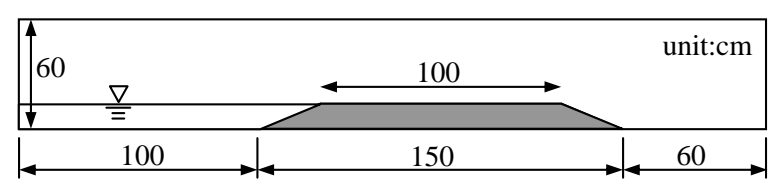

図-1 堰形状

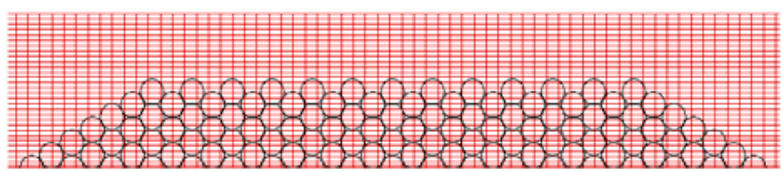

図-2 DEM 初期パッキング結果と VOF メッシュ

て粒子の運動を解析する.また，粒子間の力の伝達は接 触点でのみ起こるものとしている，なお，本研究で使用 したモデルは, 後藤ら ${ }^{16)}$ の DEM コードに捨石堰の流れ に起因する外力項を付加したものである.

粒子 $i$ における座標 $\left(x_{i}, z_{i}\right)$, 角速度 $\theta_{i}$ に関寸る基礎式 は，接触粒子を $j$ とおくと以下のように表される。

$$
\begin{gathered}
\left(M_{i}+M_{i}^{\prime}\right) \ddot{x}_{i}=\sum_{j}\left\{-f_{n} \cos \alpha_{i j}+f_{s} \sin \alpha_{i j}\right\}_{j}+F_{x} \\
\left(M_{i}+M_{i}^{\prime}\right) \ddot{z}_{i}=\sum_{j}\left\{-f_{n} \sin \alpha_{i j}+f_{s} \cos \alpha_{i j}\right\}_{j} \\
-\left(M_{i}-\rho_{w} V_{i}\right) g+F_{z} \\
I_{i} \ddot{\theta}_{i}=\frac{d_{i}}{2} \cdot \sum_{j}\left\{f_{s}\right\}_{j}
\end{gathered}
$$

ここで, $M_{i}$ : 粒子の質量, $M_{i}^{\prime}$ : 付加質量, $\alpha_{i j}$ : 粒子 $i, j$ の接触角, $f_{n}, f_{s}$ : 粒子 $i, j$ 間の法線および接線方向 の作用力, $F_{x}, F_{z}$ : 粒子に作用する $x$ 方向および $z$ 方向 の流体力, $V_{i}$ : 粒子の体積, $I_{i}$ : 粒子の慣性モーメント, $d_{i}$ : 粒径, $\rho_{w}$ : 水の密度である. なお, 付加質量 $M_{i}^{\prime}$ は 付加質量係数 $C_{M}$ を用いて, $M_{i}^{\prime}=\rho_{w} C_{M} V_{i}$ で表される. $C_{M}$ には 0.5 を用いた. また, 流体から受ける外力 $F_{x}$ お よび $F_{z}$ としては前野ら ${ }^{12)}$ と同様に, 流れによる力と圧力 勾配による力を考慮し, バネ定数, 粘性定数等のモデル 定数は後藤ら ${ }^{16)}$ と同様の方法により,$\alpha_{t n}=20.0$ および $\alpha_{c n}=1.3$ を与えた.

\section{（3）解析モデルと解析条件 \\ (a) 解析対象モデル}

図-1 は, 本研究で採用した堰構造物の形状である.こ

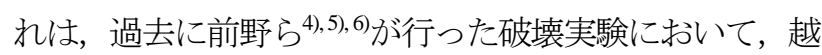
流時に破壊の起こる粒径 $4.8 \mathrm{~cm}$ の場合を対象としてモデ ル化したものであ. 図-2 には, VOF 法における解析メ ッシュと DEM の初期パッキング結果を示している. 本 研究では, 粒子の初期配列を決定するために, 各要素間 と河床との間にわずかな間隙を残した非接触状態から， 自由落下を想定した計算を行い，要素のパッキングを行 った. 全ての要素がほぼ停止した時点でパッキング完了 と判断した. パッキングに要した時間は 0.8 秒である. 実験では, 下流側最下層の石碟を河床に固定しているた め, 本モデルも，最下層の最も下流側の 1 粒子を固定粒 子として，移動を制限している，VOF 法では， $x$ 方向に 


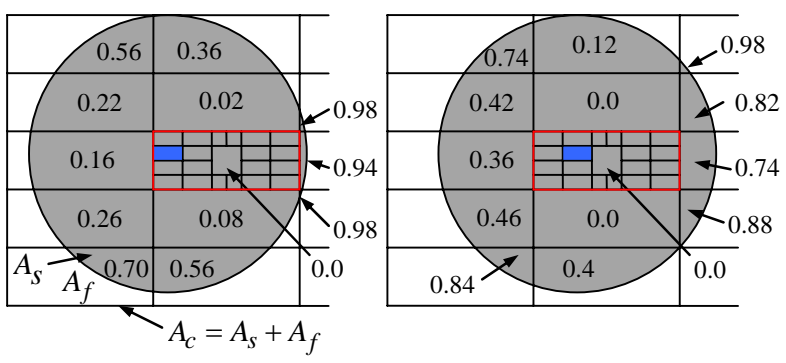

図-3＼cjkstart間隙率の補正と更新（概念図）

$2.5 \mathrm{~cm}, z$ 方向に $1.0 \mathrm{~cm}$ 間隔でメッシュを設定している. なお， $z$ 方向の最下段のメッシュのみ間隔が $0.5 \mathrm{~cm}$ であ るのは，流量が少ない場合など水位が低い時に，計算が 不安定になるのを避けるためである.

\section{(b) 計算条件}

流量に関しては, 破壊実験と前野らの解析結果から， 15(l/s)前後で法面の抜け出し破壊が起こり，その後段階 的に破壊が進行していくと予想されることから，幅を持 たせて 10２5(l/s)までとし，120 秒間かけて線形的に増 加させた. パラメータの設定については, 計算時間ステ ップを $\Delta t=1.0 \times 10^{-4}(\mathrm{sec})$ として, 付加質量係数 $C_{M}$ は 1.0, 粒子間の摩擦係数は木山ら ${ }^{17)}$ を参考に $\mu=0.577$, 粒 子と壁との摩擦係数は $\mu=0.176$ とした.

\section{（4） VOF-DEM の連成方法}

VOF 法で多孔質部を解析する場合には，式(2)〜式(4) に示すように，流れ場を支配する基礎式に間隙率が必要 となる. また, 式(5)〜式(7)に示すように, 流体が多孔質 体から受ける抗力の算定においても間隙率が重要な要素 となる．よって，捨石およひ砂粒子の変形やかみ合わせ の変化による間隙率の変化は, 流体部と多孔質体境界付 近の流体運動に大きな影響を与えるため, VOF-DEM の 連成にあたっては，DEM 粒子の移動に伴う間隙率の変 化を更新し, VOF 法へフィードバックするモデルが必要 となる. 前野ら ${ }^{15)}$ は潜堤を対象とした VOF-DEM-FEM 連 成モデルにおいて，メッシュサイズよりも小さな粒子を 対象とした連成手法を提案しているが，DEM 粒子がメ ッシュサイズよりも大きい場合には適用できないため, 本研究では，以下のような方法を採用した.

図-3 は, 図-2 におけるある粒子部分を拡大して示した ものであり, 図の青い塗りつぶしの部分の中心に粒子の 中心が位置しているものとする. 図中の数字はその時の 各セルにおける間隙率を示している. 単純に 2 次元場の 粒子配列から得られる間际率をそのまま用いると, 円柱 粒子を仮定しているため，例えば，粒子の中心が位置す る VOF セル（図の赤枠の部分）では, 図に示すように 間隙率が 0 となり，3 次元的なかみ合わせをもつ実際の 粒子配列からなる間隙率と一致しなくなる. そこで本研 究では, 各セルに占める粒子面積 $A_{s}$ を算出した後, 実験 により得られた捨石部の間隙率 $n_{\exp }$ を 0.41 として, 間 隙率 $n$ を以下のように補正した。

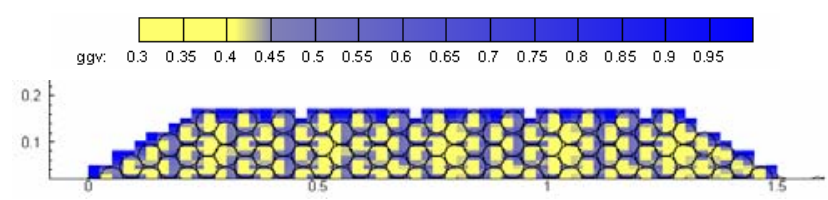

図-4 空隙率の分布

$$
n=\left(A_{f}+A_{s} n_{\exp }\right) /\left(A_{f}+A_{s}\right)
$$

ここに， $A_{f}$ は各セルに占める粒子円外の間隙面積であ り, 間隙率が定義されるセルの面積を $A_{c}$ とすると, $A_{c}$ $=A_{s}+A_{f}$ である.

このようにして間隙率を算出できるが，微小な粒子位 置の移動による間隙率の変化をその都度計算すると解析 に対する時間的な負荷が大きくなる，そこで本研究では あらかじめ図-3に示すように, 粒子の中心が存在するセ ルをさらに 21 個に小分けにした小セルの中に粒子の中 心が位置するそれぞれの場合について，粒子の存在する 各セルに占める粒子面積 $A_{s}$ を算出しておき, 粒子位置の 判定のみで間隙率を与えることができるようにした. 図 より, 同じセル内であっても, 各セルの間隙率が異なる のがわかる，セル内に他の粒子がある場合には，粒子の 占有面積 $A_{s}$ を重㸚合わせて間隙率を算出した.

以上のように粒子周りのセルに間隙率を持たせること で, 多孔質体内ではほぼ間隙率が実験值に近い 0.41 とな った(図-4)，さらに，粒子位置が変化することによって 間隙率も更新されるため, VOF 法における多孔質抵抗を 適切に評価できるようになる。

\section{(5) 実験の概要}

\section{(a) 捨石堰の実験結果}

前野ら ${ }^{4,5)}$ の捨石堰の実験によると, 通水流量の増加に 伴い，まず，堰下流法面にある特に噛み合わせの弱い石 磎が 2,3 個抜け出寸初期破壊が発生するが，堰本体は崩 れない. その後, 下流側法面の粒子が浮き上がり, 抜け 出そうとするが, 下側の粒子との噛み合いでロックされ る.さらに流量を増加させていくと, 法面中央付近の粒子 が完全に抜け出し，それに伴い上側の粒子が転がり落ち てくるために法肩まで崩壞する第 2 段階の破壊が発生す る.ここでいったん堰は安定するが，流量を増やしてい くにしたがって，天端付近の粒子が崩壊し，大きな崩れ を見せる 3 次的， 4 次的な破壊一と段階的に進むことが 分かっている.

\section{(b) 捨石堰法面石礫の引つ張り実験}

過去の実験に加え, 今回初期破壊における解析モデル の妥当性を明らかにするために, 簡単な実験を行った.

図-5に示寸ように, 過去の実験, 解析から初期破壊の起 こる法面の石碟を鉛直, 水平, 斜めの 3 方向からモ一メ ントが加わらないように力を加え, どの程度で抜け出す のかをバネはかりを用いて空気中で測定した。 ここで, 斜め方向とは，堰の法面に対して垂直な方向である．ま た，堰の法面の勾配は前野ら ${ }^{4)}$ 5)の実験を参考に，270程 
度とした. 表-1 は, 10 回行って得られた各方向の抵抗力 の平均值である，その結果，堰の法面粒子の，鉛直，斜 め方向の引っ張りに対する抵抗力は, 水平方向のそれに 比べていずれも 6 割程度しかないことがわかる。このこ とは, 前野ら ${ }^{12}$ が解析で示したように, 法面粒子の抜け 出しには圧力勾配に起因寸る法面に垂直な力の影響が大 きいという解析結果と一致する.

\section{3. 解析結果と実験との比較}

\section{（1）破壊過程}

まず, 解析スタート時の流量である 10(1/s)から徐々に 流量を増やすが，しばらくは，粒子の移動は見受けられ なかった.ささらに流量を増やし，15(1//s)を越えるあたり から, 法面中央付近の粒子が少し浮き上がってくるが, 噛み合わせの影響で抜け出しには至らなかった．実験で は初期段階の破壊は, 流量約 14(1//s) の時点で噛み合わせ の特に弱い粒子が抜け出し，脱落したが，本解析で初期 段階の法面粒子の抜け出しが見られなかったのは, パッ キング時の粒子の噛み合わせが良好なためであったと考 えられる. 初期破壊過程は再現出来なかったが，実験に おける初期破壞も大きな形状の変化を伴わないものであ るため, 予測精度上の問題はないと思われる。

図-6 は，計算開始後 56.8 秒経過し，流量が約 17.1(l/s) まで増加した時に発生した下流側法面付近の第 2 段階の 破壊の様子を示している．各図の上部にあるのは，計算 開始後の時刻とその時の流量であり, オレンジ色で囲っ た枠は，破壊の様子の確認のために捨石堰の初期形状の 概略を示したものである. 図より，まず，浮き上がって いた法面中央付近の粒子が抜け出し，それに伴い上側の 粒子が落ちてくることがわかる.これは過去の研究でも 明らかなように, 法面中央付近の粒子に作用寸る流体力 の影響が表れたもので，本解析モデルでも同じ動きが確 認された. さらに法肩の粒子も流れに押し出される形で 破壊していった。 これにより，破壊が法面から法肩へと 進む様子が確認できる.さらに, 水色の矢印は流れの流速 を示しているが，これを見ると，粒子の抜け落ちた箇所 に水が浸入してくるのが分かり, 空隙率の変化に伴う流 れの変化も再現できたと言える. 破壊の起こった際の流 量に関しても, 実験值 $16.5(\mathrm{l} / \mathrm{s})$ と同程度であり, 実験経 過をよく再現できている.

第 2 段階の破壊の後, 法面に残つた粒子の一つが流れ に押し出されて破壊したが，それ以外に目立った破壊は 発生せず，堰はいったん安定を見せた。 その後も徐々に 流量を増加させると, 2 段階の破壊から約 16 秒後, 流量 約 19.2(l/s)の時に, 第 3 段階の破壊が発生した. 図-7 はそ の破壞の様子を示したものである. 第 2 段階の破壊と異 なり，今度は法面の破壊により表面に出てきた天端部の 粒子 2 つが破壊していく様子が分かる. 移動した粒子の うち上流側の粒子は，下流側の粒子があった場所に落ち

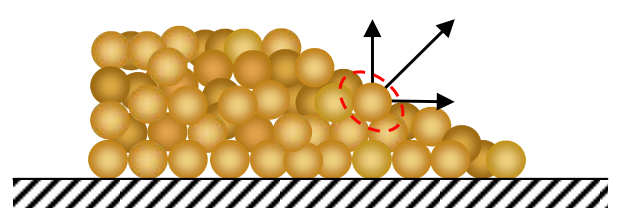

図 -5 引つ張り実験概略図

表-1 各方向の抵抗值

\begin{tabular}{|c|c|c|}
\hline 鉛直 & 斜め & 水平 \\
\hline $2.81 \mathrm{~N}(287 \mathrm{~g})$ & $3.04 \mathrm{~N}(311 \mathrm{~g})$ & $4.75 \mathrm{~N}(485 \mathrm{~g})$ \\
\hline
\end{tabular}

込んで停止した．実験では第 3 段階の破壞は 20.4 (1/s)で 発生しており，本解析は第 3 段階の破壊も概社予測でき たことがわかる。

以上のように，捨石堰の破壊は下流側法面の粒子の抜 け出しによって始まり, その後, 法肩, 天端部へと移行 していく様子を再現できた。 また，捨石堰の破壊が安定 期と破壊を交互に繰り返すという実験結果も概衫再現で きたといえる. 各段階の破壞が起こった際の流量も実験 結果とほぼ一致しており, 本解析モデルは, 今後設置さ れる捨石構造物の破壊予測モデルとして有効であること が示された.

\section{（2）圧力勾配による力及び流れによる抗力}

図-8 は，法面の抜け出し破壊が起こる時と，天端部の 粒子が脱落する時の各粒子に作用する圧力勾配による力

（以下では圧力勾配力と寸る）の大きさを示したもので ある. また，破線で囲った粒子は，直後に移動を起こす 粒子を示したものである. 従来の研究により, 法面粒子 の抜け出しには，圧力勾配力の影響が大きいことが分か っている. 図-8 からも見て取れるように，抜け出しを起 こす粒子には比較的大きな力が作用していることが分か る. また, 特徵的には, 水平方向の力に加えて, 法面に 垂直な向きの力が作用している. これは，抜け出し破壊 の特徵である，鉛直もしくは法面に垂直な方向の力に対 する法面粒子の抵抗力が比較的弱いという実験結果と概 ね一致するものである. また, 第 3 段階の破壊の特徵で ある天端部の粒子の破壊も，同様に法面に垂直な方向一 の圧力勾配力が大きい. このことから, 本解析モデルに おいては, 抜け出し破壞の後, 段階的に起こる破壊も, 圧力勾配力の影響が大きいと結論付けることが出来る.

図-9 は，圧力勾配力分布と同時刻における，流れによ る抗力の分布図を示している. 法肩付近で比較的大きな 值を見せるが，圧力勾配力と比較すると粒子の抜け出し 破壊への影響は比較的小さいと思われる。

\section{（3）捨石堰周辺の流れ}

図-10 は, 解析スタート時から, 流量の増加に伴い変 化する捨石堰周辺の流れの流速分布を示したものであ る.

まず,一様に近づいてきた流れが捨石堰にぶつかり,一 
$Q=17.1(\mathrm{I} / \mathrm{s}) \quad 56.8(\mathrm{~s})$

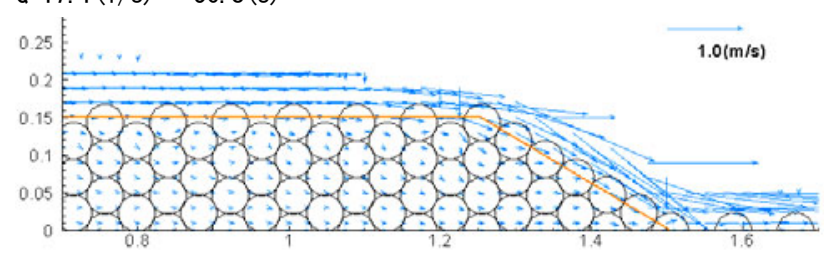

$Q=17.15(\mathrm{I} / \mathrm{s}) \quad 57.2(\mathrm{~s})$

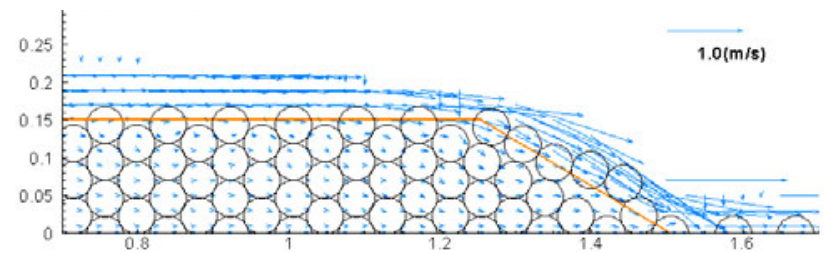

$Q=17.20(\mathrm{I} / \mathrm{s}) \quad 57.6(\mathrm{~s})$

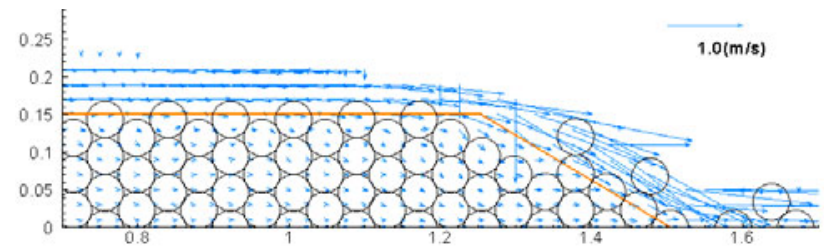

$Q=17.25(\mathrm{I} / \mathrm{s}) \quad 58.0(\mathrm{~s})$

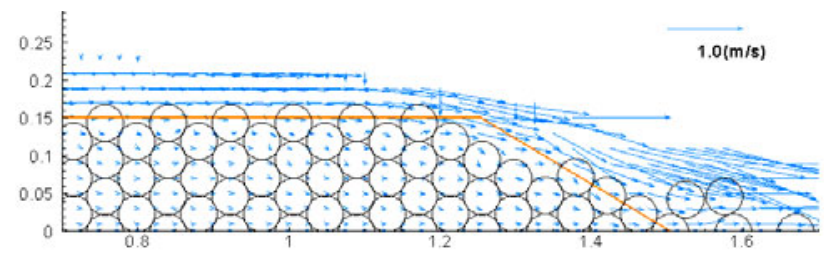

図-6 第 2 段階破壊時の法面部分の破壊過程

$56.8(s)$

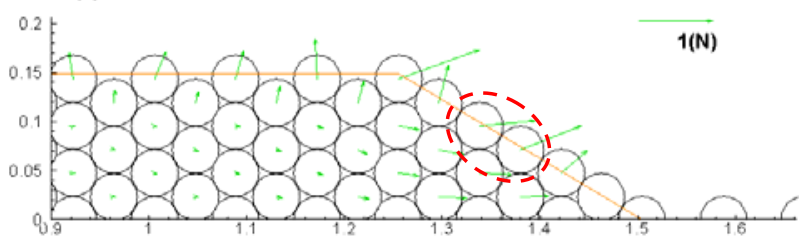

(a) 第 2 段階破壊時の抗力分布 (法面部分粒子破壊時)

73. $6(s)$

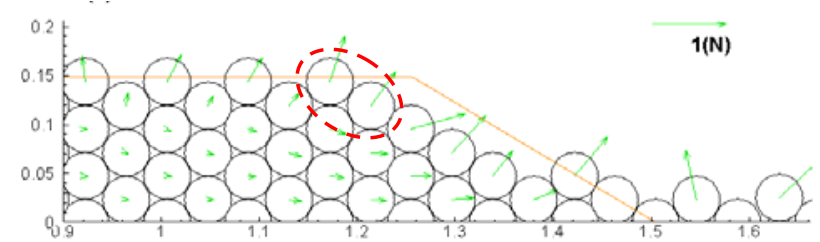

（b）第 3 段階破壊時の圧力勾配力分布 （天端部分粒子破壊時）

図-8 破壊直前の粒子にかかる圧力勾配力分布

部は堰体内に侵入するが，大部分は堰の上流側法面に沿 って上昇し，天端に流れ込むことが分かる．さらに下流 側法肩付近で堰体内に侵入寸る流れが増加し，下流側法 面から出水している. 過去の実験からもこのような特徵 が確認されており，実験を概ね再現できたといえる。 た，流量増加に伴い堰天端上部を流れる流速は増加し，
$Q=19.2(\mathrm{I} / \mathrm{s}) \quad 73.6(\mathrm{~s})$

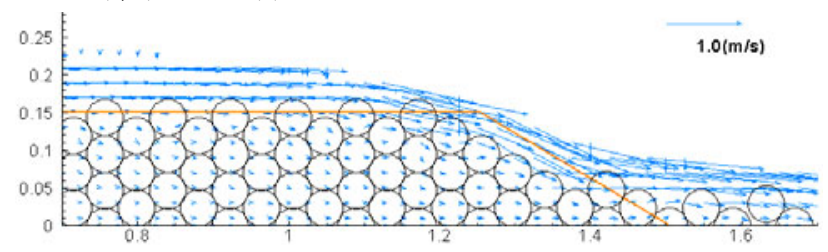

$Q=19.25(\mathrm{I} / \mathrm{s}) \quad 74.0(\mathrm{~s})$

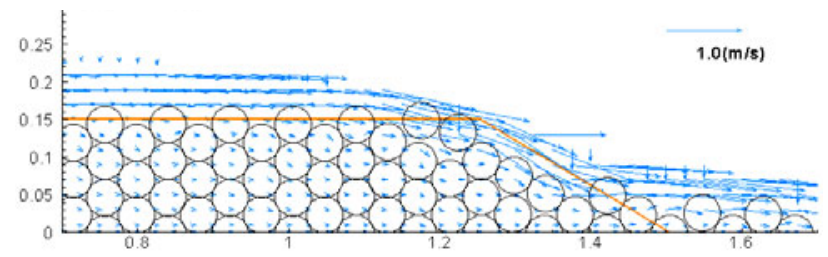

$\mathrm{Q}=19.30(\mathrm{I} / \mathrm{s}) \quad 74.4(\mathrm{~s})$

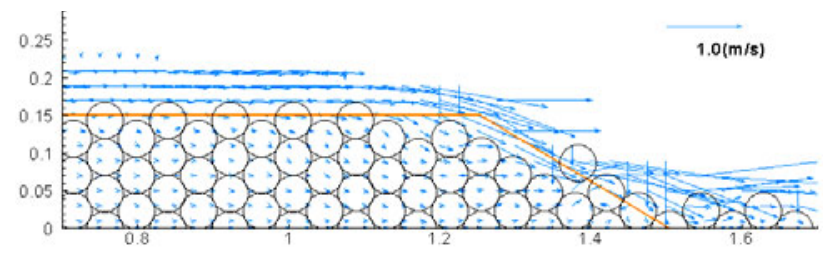

$Q=19.35(\mathrm{I} / \mathrm{s}) \quad 74.8(\mathrm{~s})$

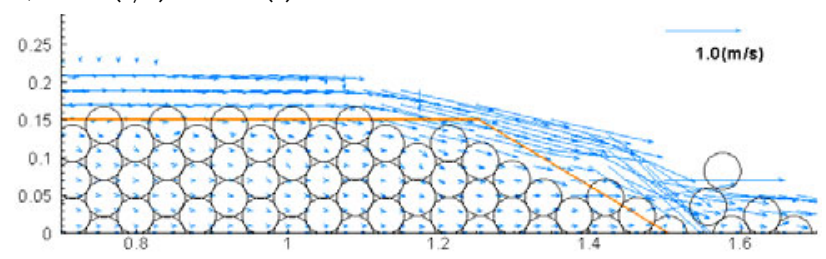

図-7 第 3 段階破壊時の天端部分の破壊過程

56. $8(\mathrm{~s})$

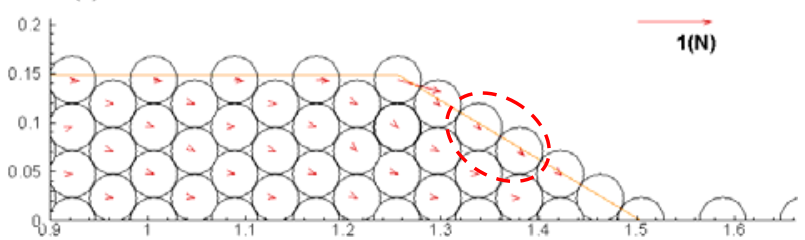

(a) 第 2 段階破壊時の抗力分布 (法面部分粒子破壊時)

73. $6(\mathrm{~s})$

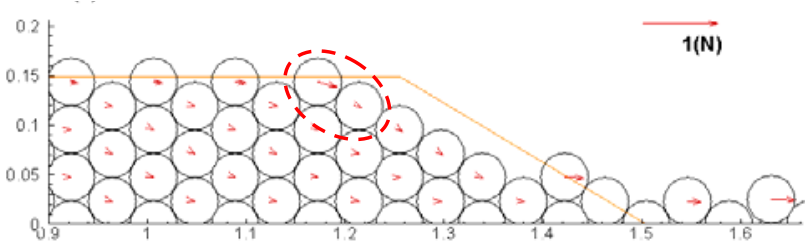

(b) 第 3 段階破壊時の抗力分布 (天端部分粒子破壊時)

図-9 破壊直前の粒子にかかる抗力分布

水位も流量とともに増加している. さらに，オレンジ色 の枠は捨石堰の形状の概略を示したものであるが，堰の 破壊に伴う流れの変化や，堰を通過した流体の流れも前

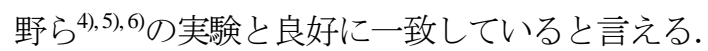

\section{4. 結論}



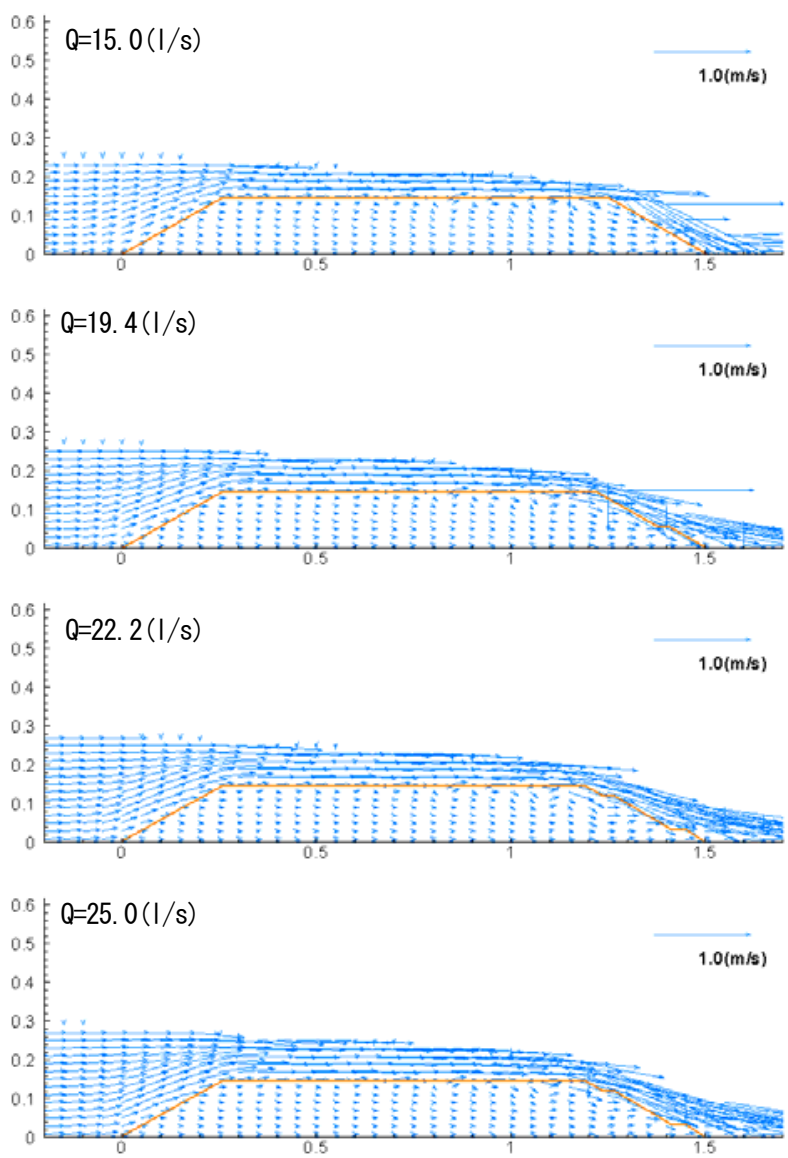

図-10 捨石堰周辺の流れ

本研究では, 捨石堰を対象として流量を徐々に増加さ せた際の流体力の変化を VOF 法により計算し, 得られ た流体力を石碩に働く作用力として DEM 解析に順次組 み込むことで，捨石堰の破壊過程を捉えるシミュレーシ ヨンを行った. これによって得られた結果を以下にまと める.

1) VOF 法と DEM を連成させた本解析モデルによって, 粒子の移動とそれに伴う流体部の変化を同時に追跡でき た

2) 下流側法面中央付近の石碩の抜け出しから始まり, 法 肩，天端部へと移行していく捨石堰の破壊の様子を再現 できた

3) 捨石堰の破壊は, 安定期と破壊を交互に繰り返すこと が再現できた。

4) 捨石堰の法面粒子の抜け出しには法面粒子に作用す る圧力勾配による力の影響が大きいという破壊特性が明 らかになった。

今後は，粒子の積み上げ方や，勾配の違いによる破壊 過程のシミュレーションを行うとともに，実際の粒径に 近い混合粒径での解析を行い，モデルの精度をさらに向 上させる必要がある．また，本研究では，法面粒子の破 壊力の計測実験は静的な条件で行い，実際の流れの中で の捨石堰の破壊の計測は行っておらず，粒子が流体から 受ける外力の妥当性の検証が十分できていない．したが
って，今後は，破壊時の作用力に関する実験を行い，よ り現実に即したデータを得る必要がある.

\section{参考文献}

1) 道奥康治，前野詩朗，羽根田正則，古澤孝明 : 捨石堰を越 流・透過する流れの構造と流量解析，土木学会論文集， No.740, pp.131-142, 2003.

2) 道奥康治，福岡達信，古澤孝明 : 捨石堰における通過流量 特性，水工学論文集, 第 45 巻, pp.391-396, 2001.

3) 道奥康治, 前野詩朗, 古澤孝明, 羽根田正則 : 捨石堰の「水 位一流量」特性を規定する水理量，水工学論文集，第 46 巻, pp.487-492, 2002.

4) 前野詩朗, 道奥康治，森永智，大西利典：自然石を用いた 堰の水理特性，水工学論文集，第 46 巻, pp.493-498, 2002.

5) 前野詩朗, 道奥康治, 大西利典, 森永智 : 捨石堰の破壊時 の水理特性，応用力学論文集，Vol.5, pp.657-664, 2002.

6) 前野詩朗, 道奥康治, 森永智, 大西利典 : 捨石堰の破壊機 構のモデル化，水工学論文集，第 47 巻, pp.781-786, 2003.

7) 前野詩朗，小川誠，道奥康治 : 鉛直 2 次元モデルによる多 孔質堰を通過する流れの解析, 土木学会論文集, Vol.63 No.1, pp.16-28, 2007.

8) 磯部雅彦，高橋重雄，余錫平，柇山勉，藤間功司，川崎浩 司，蒋勤，秋山実，大山洋志 : 数值波動水路の而波設計へ の適用に関する研究-VOF 法基本プログラムの作成-, 海洋 開発論文集，第 15 巻, pp.321-326, 1999.

9) 伊藤一教，東江隆夫，勝井秀博：DEM 法と VOF 法を用い た粒状体構造物の破壊シミュレーション, 海岸工学論文集, 第 47 巻, pp.746-750.2000.

10）伊藤一教，樋口雄一，東江隆夫，勝井秀博 : 個別要素法に 基づく捨石のランダム性を考慮した潜堤の変形予測手法, 海岸工学論文集，第 48 巻，pp.806-810.2001.

11）荒木進歩, 小竹康夫, 金澤 剛, 松村章子, 出口一朗 : VOF 法と個別要素法の連成解析による傾斜捨石護岸の変形予 測，海岸工学論文集，第 48 巻，pp.931-935.2001

12) 前野詩朗, 道奥康治, 加瀬瑛斗, 菊池慶太 : 個別要素法を用 いた捨石堰の破壊予測，水工学論文集，第 49 巻, pp.787-792, 2005.

13) Edward, C. C., L. Fue-Sang and M. M. Yovanovich : Numerical study of forced flow in a back-step channel through porous layer , 34th, ASME Narional Heat Transfer Conference, pp. 1-6.2000.

14）道奥康治，南條雅志，石垣泰輔，前野詩朗 : 捨石水制が冠 水した開水路流の二次元二層流モデル，土木学会論文集， No.782/II-70, pp. 31-50.2005.

15）前野詩朗, 小川 誠, Bierawski, L.G : VOF-DEM-FEM モデ ルによる潜堤の挙動解析, 海岸工学論文集, pp. 886-890, 第 53 巻, 2006. 11 .

16) 後藤仁志，林 稔，酒井哲郎：固液二相流型 MPS 法に よる波・底泥相互干涉の数值解析, 海岸工学論文集, 第 48 巻, pp.1-5.2001.

17）木山英郎，藤村尚 : カンドルの離散剛要素法を用いた岩質 粒状体の重力流動の解析，土木学会論文集，第 333 号, pp.137-146.1983.

(2007. 9. 30 受付) 